\title{
HUBUNGAN PEMBERIAN REINFORCEMENT ORANGTUA DENGAN PERILAKU BULLYING PADA SISWA SMP PERGURUAN KSATRYA JAKARTA PUSAT
}

\author{
Ika Mustafida ${ }^{1)}$ Nurhayati $^{2)}$ \\ 1) PSIK - FIK Universitas Muhammadiyah Jakarta; Akademi \\ Keperawatan RS Husada Jakarta \\ 2) Dosen PSIK - FIK Universitas uhammadiyah Jakarta \\ Email: ikamustafida@yahoo.com
}

\begin{abstract}
ABSTRAK
Bullying adalah tindakan agresif yang dilakukan berulang-ulang dengan niat mengancam atau menakut-nakuti orang yang lebih lemah dari pelakunya. Pemberian reinforcement orangtua diharapkan mampu menekan perilaku bullying yang terjadi. Tujuan penelitian ini adalah untuk mengetahui hubungan antara reinforcement orangtua terhadap perilaku bullying pada siswa SMP Perguruan Ksatrya Jakarta. Metode penelitian menggunakan desain deskriptif crossectional dengan teknik accidental sampling. Jumlah sampel penelitian berdasarkan rumus sebanyak 190 responden. Penelitian ini dianalisa menggunakan distribusi frekuensi dan uji chi square. Hasil penelitian menunjukkan sebanyak 83 orang $(63,4 \%)$ responden yang tidak berperilaku bullying dengan jenis reinforcement positif dari orangtua dan 48 orang $(36,6 \%)$ responden yang berperilaku bullying dengan jenis reinforcement positif dari orangtua. Pada uji statistik dengan derajat kepercayaan 95\% dan nilai Alpha $=0,05$, didapatkan nilai $p$ value $=0,034$ maka disimpulkan ada hubungan yang signifikan antara pemberian reinforcement orangtua terhadap perilaku bullying pada siswa SMP Perguruan Ksatrya Jakarta. Saran dari hasil penelitian orangtua perlu memberikan reinforcement positif kepada remaja untuk menekan perilaku bullying pada remaja.
\end{abstract}

Kata Kunci: Bullying, Perilaku, Reinforcement Orangtua

\begin{abstract}
Bullying is an aggressive action that continuous with the purpose to threatening and scaring other weak people. Awarding parental reinforcement can be expected to reduce bullying behavior. The purpose of this research is to determine the correlation between parental reinforcement with bullying behavior in junior high school students of Perguruan Ksatrya Jakarta. This research use descriptive crossectional design as a method and accidental sampling technique. As many as 190 samples in this research. This research analyzed with frequency distribution and chi square test. The results showed as many as 83 students (63,4\%) who not behave bullying with positive reinforcement from their parents, and 48 students $(36,6 \%)$ who behave bullying with positive reinforcement from their parents. In statistic test with confidence interval 95\% and Alpha 0,05, obtained $p$ value 0,034. It can be inferred that there is significant correlation between parental reinforcement with bullying behavior in junior high school students of PerguruanKsatrya Jakarta. The implication from this research is parents have to give positive reinforcement to adult to reduce bullying behavior.
\end{abstract}

Keywords: Behavior, Bullying, Parental reinforcement 


\section{PENDAHULUAN}

Menurut Santrock (2003), remaja diartikan sebagai masa perkembangan transisi antara masa anak sampai masa dewasa yang mencakup perubahan biologis, kognitif dan sosial-emosional. Masa remaja terdiri atas 3 subfase yaitu masa remaja awal usia 11-14 tahun, masa remaja pertengahan usia 15-17 tahun, masa remaja akhir usia18- 20 tahun (Wong et al, 2008). Dalam buku "Psycology of Adolescene" Karl C.Garrison (2003), Remaja memiliki 7 macam kebutuhan yang menjadi esensi pertumbuhan dari segi psikologis mereka, diantaranya adalah kebutuhan akan kasih sayang, diterima dalam kelompok, mandiri, berprestasi, dihargai, mendapat pengakuan sebagai wujud memperoleh prestise, dan memperoleh falsafah hidup. Tidak terpenuhinya kebutuhan tersebut dapat menimbulkan perilaku menyimpang yang dilakukan oleh remaja.Perilaku menyimpang yang terjadi dapat berupa merokok, tawuran, bolos sekolah, pemalakan, penyimpangan seks, penyalahgunaan obat dan pembunuhan serta bullying.

Bullying didefinisikan sebagai suatu bentuk abuse emosional atau fisik (Storey, 2008). Beberapa kasus yang meluap di media belakangan ini antara lain kasus bullying yang dilakukan oleh senior di Sekolah Tinggi Ilmu Pelayaran (STIP) Jakarta kepada Dimas Handoko yang tewas dikeroyok pada awal Mei 2014 (Ventura, 2014). Kasus lainnya adalah meninggalnya Renggo, siswa SD Makasar Jakarta yang disebabkan karena dianiaya oleh kakak kelasnya. Perilaku bullying lainnya dapat dilihat dari banyaknya video kekerasan siswa SMP yang beredar di media Youtube yang berjumlah 6530 video.

Berdasarkan data yang diperoleh dari Komisi Nasional Perlindungan Anak (KomNas PA) dan Komisi Perlindungan Anak Indonesia (KPAI), pada tahun 2011 terdapat 139 kasus bullying, sedangkan pada tahun 2012 menurun menjadi 36 kasus tercatat sebagai tindakan bullying dan pada tahun 2013 kembali meningkat dengan data 91 kasus bullying. Sedangkan pada tahun 2014, Ketua Umum Komisi Nasional Perlindungan Anak, Arist Merdeka Sirait menegaskan, kekerasan pada anak sudah sangat mengerikan dan bisa dikatakan pada tahap darurat karena dalam tiga bulan pertama 2014, KomNas PA menerima 252 laporan kekerasan pada anak yang diperoleh baik dari pengaduan langsung, melalui surat, melalui telpon, melalui email dan melalui 
media online, cetak serta elektronik (Auliani, 2014).

Salah satu penyebab terjadinya bullying adalah keluarga. Anak akan mempelajari perilaku bullying ketika mengamati konflikkonflik yang terjadi pada orang tua mereka, dan kemudian menirunya terhadap temantemannya (Ariesto dalam Mujijanti, 2011). Keluarga khususnya orang tua sangat berperan dalam mereduksi perilaku bullying remaja dengan memberikan perhatian pada anak remajanya. Bentuk perhatian orang tua yang dapat dilakukan sesuai dengan tugas tahap tumbuh kembang keluarga adalah mempertahankan komunikasi terbuka antara orangtua dan remaja dan memelihara hubungan intim antar anggota keluarga (Harnilawati, 2013).

Salah satu hal yang dapat orang tua lakukan untuk mencapai tugas perkembangan keluarga diatas adalah dengan melakukan pendekatan dengan cara pemberian reinforcement atau penguatan. Selain untuk menncapai tugas tahap tumbuh kembang keluarga dengan anak remaja, penguatan (reinforcement) juga merupakan salah satu cara untuk mengatasi bullying pada remaja (Syaodih, 2007). Dari tabel 2 dapat dilihat bahwa jumlah jenis kelamin siswa yang terbanyak adalah lakilaki.

\section{METODE}

Desain penelitian yang digunakan pada penelitian ini adalah desain deskriptif crossectional. Populasi dalam penelitian ini adalah siswa-siswi kelas VII, VIII, IX SMP Perguruan Ksatrya Jakarta yang berjumlah 363 orang. Jumlah sample pada penelitian ini sebanyak 190siswa. Teknik pengambilan sampel yang digunakan adalah accidental sampling. Analisis statistik dilakukan dengan program SPSS 19. Uji statistik yang digunakan adalah uji Chi square dengan tingkat kemaknaan 95\%. Nilai P Value dianggap bermakna jika $<0,05$.

\section{HASIL}

Hasil distribusi frekuensi menunjukkan, dari tabel 1 distribusi frekuensi usia, dapat dilihat bahwa usia siswa yang terbanyak adalah kelompok usia remaja awal.

Tabel 1

Distribusi Kelompok Usia Siswa

\begin{tabular}{lccc}
\hline \multicolumn{1}{c}{ Usia } & Frekuensi & & Persentase (\%) \\
\cline { 1 - 1 } Remaja Awal & & 174 & 91,6 \\
Remaja Pertengahan & 16 & & 8,4 \\
Remaja Akhir & & 0 & 0 \\
Total & $\underline{190}$ & $\underline{100}$ \\
\hline
\end{tabular}

Tabel 2

Distribusi Jenis Kelamin Siswa 


\begin{tabular}{|c|c|c|}
\hline $\begin{array}{l}\text { Jenis Kelamin } \\
\text { Siswa }\end{array}$ & Frekuens & $\frac{\text { Persentase }}{(\%)}$ \\
\hline Laki-laki & $\begin{array}{c}11 \\
2\end{array}$ & $\begin{array}{c}58, \\
9\end{array}$ \\
\hline Perempuan & 78 & 41 \\
\hline Total & 190 & 100 \\
\hline \multicolumn{3}{|c|}{$\begin{array}{l}\text { Dari tabel } 3 \text { dapat dilihat bahwa jumlah } \\
\text { tingkat pendidikan orangtua siswa terbanyak } \\
\text { adalah Tinggi. }\end{array}$} \\
\hline & $\begin{array}{l}\text { Tabel } 3 \\
\text { didikan Oran }\end{array}$ & stua Siswa \\
\hline $\begin{array}{l}\text { Tingkat } \\
\text { Pendidikan } \\
\text { Orangtua }\end{array}$ & $\underset{\text { si }}{\text { Frekuen }}$ & $\begin{array}{c}\text { Persentase } \\
(\%)\end{array}$ \\
\hline $\begin{array}{l}\text { Rendah (SD-SMP) } \\
\text { Tinggi (SMA-PT) } \\
\text { Total }\end{array}$ & $\begin{array}{l}52 \\
138 \\
190\end{array}$ & $\begin{array}{l}27,4 \\
72,6 \\
100\end{array}$ \\
\hline
\end{tabular}

Dari tabel 4 didapatkan pekerjaan orangtua siswa terbanyak adalah wiraswasta.

Tabel 4

Distribusi Pekerjaan Orangtua Siswa

\begin{tabular}{lccc}
\hline \multicolumn{1}{c}{ Pekerjaan } & Frekuensi & & Persentase (\%) \\
\cline { 1 - 1 } Buruh & 29 & & 15,3 \\
Wiraswasta & 85 & & 44,7 \\
Karyawan Swasta & 59 & & 31,1 \\
PNS/ABRI/POLRI/TNI & 17 & & 8,9 \\
Total & $\underline{190}$ & & 100 \\
\hline
\end{tabular}

Dari tabel 5 didapatkan jenis reinforcement yang diterima siswa dari orangtua terbanyak adalah reinforcement positif.

Tabel 5

Distribusi Reinforcement Orangtua Siswa

Dari tabel 6 didapatkan bahwa mayoritas siswa di SMP Perguruan Ksatrya Jakarta tidak berperilaku bullying .

Tabel 6

Distribusi Perilaku Bullying Siswa

\begin{tabular}{lccc}
\hline \multicolumn{1}{c}{ Perilaku Bullying } & Frekuens & & Persentase \\
\cline { 2 - 3 } Non Perilaku & 11 & & 57, \\
Bullying & 0 & & 9 \\
Perilaku Bullying & 80 & & 42, \\
Total & $\underline{190}$ & 100 \\
\hline
\end{tabular}

Berdasarkan hasil analisis bivariat dengan chi square, didapatkan ada sebanyak 83 orang $(63,4 \%)$ siswa yang tidak berperilaku bullying dengan jenis reinforcement positif dari orangtua dan 48 orang $(36,6 \%)$ siswa yang berperilaku bullying dengan jenis reinforcement positif dari orangtua. Sedangkan terdapat 27 orang $(45,8 \%)$ siswa yang tidak berperilaku bullying dengan jenis reinforcement negatif dari orangtua dan 32 orang $(54,2 \%)$ siswa yang berperilaku bullying dengan jenis reinforcement negatif dari orangtua. Pada uji statistik dengan derajat kepercayaan $95 \%$ dan nilai Alpha $=0,05$, didapatkan nilai $p$ value $=0,034$ maka disimpulkan hipotesis nol ditolak atau "ada hubungan yang signifikan antara pemberian reinforcement orangtua terhadap perilaku bullying pada siswa SMP Perguruan Ksatrya Jakarta". Hasil uji statistik juga diperoleh nilai OR 
sebesar 2,049 artinya bahwa pemberian

reinforcement positif mempunyai peluang

2,049 untuk menjadikan siswa tidak berperilaku

bullying dibandingkan dengan pemberian

reinforcement negatif.

\section{PEMBAHASAN}

Hasil penelitian terhadap 190 siswa SMP

Perguruan Ksatrya Jakarta, menunjukkan bahwa usia siswa yang terbanyak adalah kelompok usia remaja awal. Berdasarkan teori masa remaja terdiri atas 3 subfase yaitu masa remaja awal usia 11-14 tahun, masa remaja pertengahan usia 15-17 tahun, masa remaja akhir usia 18-20 tahun (Wong et al, 2008). Hasil penelitian ini didukung oleh data studi dari Harvard School, bahwa presentase bullying pada usia remaja 12-15 tahun lebih besar yaitu sebesar 44\% dibanding pada usia anak sekolah 7-12 tahun yaitu sebesar 20\% (NoBullying, 2013).

Hasil penelitian menunjukkan bahwa jumlah jenis kelamin siswa yang terbanyak adalah laki-laki. Hasil penelitian ini sejalan dengan teori bahwa anak laki-laki cenderung memiliki perilaku bullying lebih tinggi dibandingkan anak perempuan (Astuti, 2008). Hasil penelitian ini juga sejalan dengan penelitian Riauskia, Djuwita dan
Soesetio (2008)..

Hal ini dikarenakan tingkat pendidikan yang rendah menjadikan pengetahuan yang rendah bagi orangtua sehingga orangtua kurang mengetahui tentang pentingnya pendekatan dalam proses belajar khususnya reinforcement untuk mengubah perilaku siswa.

Hasil penelitian menunjukkan bahwa pekerjaan orangtua siswa terbanyak adalah wiraswasta. Berdasarkan teori (Santrock, 2003) Orangtua yang bekerja merupakan salah satu faktor yang mempengaruhi konflik orangtua dengan remaja. Peneliti mengasumsikan bahwa pemberian reinforcement lebih banyak pada orangtua yang bekerja sebagai wiraswasta karena memiliki jam kerja yang fleksibel sehingga komunikasi dan perhatian antara orangtua dan remaja tetap baik. 
Hasil penelitian menunjukkan bahwa jenis reinforcement yang diterima siswa dari orangtua terbanyak adalah reinforcement positif. Berdasarkan pusat studi anak di Yale University, Cara terbaik untuk menolong anak dengan masalah perilaku adalah dengan Pelatihan Manajemen Orang Tua (Parent Management Training), yang didalamnya termasuk pemberian

reinforcement terhadap anak (Kazdin, 2008). Hasil penelitian Mandy Rispoli dan Leslie Neely menyebutkan bahwa reinforcement orang tua secara spontan dapat mengurangi perilaku bermasalah pada anak (Rispoli, 2013). Sependapat dengan hasil penelitian di atas, hasil penelitian dari Asian Social Science yang ditulis oleh Dr. Safdar Rehman Ghazi bahwa keterlibatan orang tua seperti pemberian reinforcement

$$
\text { dapat meningkatkan }
$$

motivasi anak dalam belajar, sedangkan pada anak yang kurang mendapatkan reinforcement mempunyai motivasi yang rendah (Ghazi, 2010).

Hasil penelitian menunjukkan mayoritas siswa di SMP Perguruan Ksatrya Jakarta tidak berperilaku bullying. Hasil studi yang dilakukan
National Youth Violence Prevention Resource Center (Sanders, 2004) menunjukkan bahwa bullying dapat membuat remaja merasa cemas dan ketakutan, mempengaruhi konsentrasi belajar di sekolah dan menuntun mereka untuk menghindari sekolah.

Hasil pengolahan data dengan $C h i$ Square menunjukkan bahwa terdapat hubungan yang signifikan antara pemberian reinforcement orangtua terhadap perilaku bullying pada siswa SMP Perguruan Ksatrya Jakarta. Terbukti bahwa terdapat hubungan yang signifikan antara pemberian reinforcement orangtua terhadap perilaku bullying. Artinya, perilaku bullying seseorang dipengaruhi pemberian reinforcement dari orangtua.

Hasil penelitian tersebut sesuai dengan teori Harnilawati (2013) bahwa keluarga khususnya orang tua sangat berperan dalam mereduksi perilaku bullying remaja dengan memberikan perhatian pada anak remajanya. Bentuk perhatian orang tua yang dapat dilakukan sesuai dengan tugas tahap tumbuh 
kembang keluarga adalah mempertahankan komunikasi terbuka antara orangtua dan remaja dan memelihara hubungan intim antar anggota keluarga. Teori lain yang mendukung penelitian ini menurut Syaodih (2007), salah satu hal yang dapat orang tua lakukan untuk mencapai tugas perkembangan keluarga diatas adalah dengan melakukan pendekatan dengan cara pemberian reinforcement atau penguatan. Selain untuk mencapai tugas tahap tumbuh kembang keluarga dengan anak remaja, penguatan (reinforcement) juga merupakan salah satu cara untuk mengatasi bullying pada remaja.

\section{KESIMPULAN DAN SARAN}

Ada hubungan yang signifikan antara pemberian reinforcement orangtua terhadap perilaku bullying siswa SMP Perguruan Ksatrya Jakarta. Bagi dinas kesehatan disarankan melakukan tes kesehatan fisik, dan mental untuk mengidentifikasi adanya bullying dengan tanda-tanda kekerasan fisik seperti luka atau memar dan tanda-tanda kekerasan mental seperti paranoid, kecemasan, depresi, dan rendah diri.
Adanya pengawasan yang lebih ketat terhadap pihak bimbingan konseling (BK) sekolah terhadap perilaku siswa. Adanya tes untuk mengidentifikasi adanya perilaku menyimpang siswa-siswi pada ujian kenaikan kelas. Pemberian asuhan keperawatan komunitas seperti pendidikan kesehatan tentang bahaya bullying pada siswasiswi SMP dan pendidikan kesehatan kepada orangtua siswa.

Adanya konseling yang melibatkan orangtua untuk melakukan pengawasan perilaku terhadap siswa dan adanya tes psikologis untuk mengidentifikasi kepribadian dan perilaku siswa.

Remaja disarankan melakukan kegiatankegiatan yang lebih bermanfaat seperti mengikuti kegiatan ekstrakurikuler untuk menekan perilaku yang tidak bermanfaat. Orangtua disarankan terlibat dalam pengawasan kegiatan dan perilakuremaja di sekolah, memberikan reinforcement dalam bentuk positif untuk menekan perilaku negatif,serta memperbaiki komunikasi antara orangtua dengan remaja. Penelitian selanjutnya disarankan meneliti tentang efektifitas reinforcement yang diberikan orangtua pada jadwal pemberian 
tertentu terhadap perilaku remaja dengan orangtua sebagai siswa langsung. Penelitian selanjutnya juga disarankan menggunakan populasi yang lebih tersebar, misalnya menggunakan satu sekolah untuk setiap wilayah Jakarta (Utara, Timur, Pusat, Barat dan Selatan). Hal tersebut bisa membuat partisipan menjadi lebih heterogen dan lebih mewakili populasi Jakarta.

\section{DAFTAR PUSTAKA}

Alma, B. (2008). Guru profesional menguasai metode dan terampil mengajar. Bandung: Alfabeta.

Annisa. (2012). Hubungan pola asuh ibu dengan perilaku bullying remaja. Depok: Universitas Indonesia.

Anonim, (2013).General bullying statistics.

http://nobullying.com/general-

bullying-

statistics/,diaksestanggal 16

Juni 2014.

Anonim. (2013). Bullying statistics. http://www.pacer.org/bullying/a bout/ media-kit/stats.asp, diaksestanggal 19 Mei 2014.

Ardiansyah, AznanAdviis. (2008). Faktor- faktor yang mempengaruhi bullying padaremaja. Fakultas Psikologi Dan Ilmu Budaya Universitas Islam Indonesia
Arikunto. (2005). Manajemen penelitian. Jakarta: Rineka Cipta.

Ariola. (2006). Principles \& methods of research. Manila: Rex Book.

Astarini, K. (2013). Hubungan antara perilaku over protective orang tua dengan bullying pada siswa SDN Bendan Ngisor Semarang. Semarang: Universitas Negeri Semarang.

Astuti, P. R. (2008). Meredam bullying: 3 cara efektif meredam kekerasan pada anak. Jakarta: Grasindo.

Auliani, PalupiAnnisa. (2014). Indonesia

Daruratkekerasanpadaanak. http://n

asional.kompas.com/read/20 14/05/0

7/0527140/Indonesia.Darur at.Keker

asan.pada.Anak, diaksestang

gal

11

mei 2014.

Baharuddin. (2008). Pendidikan dan psikologi perkembangan. Yogyakarta: Ar- Ruzz.

Bastable, S. B. (2002). Perawat sebagai pendidik : prinsi p-prinsip pengajaran dan pembelajaran. Jakarta: EGC.

Bauman, S. (2008). The Role of elementary school counselors in redusing school bullying, the Elementary School Journal vol.108. 
Coloroso, B. (2006). Penindas, tertindas dan penuntun. Jakarta: Serambi Ilmu Semesta.

Dahlan, S. (2008). Langkah- langkahmembuat proposal penelitian bidang kedokteran dan kesehatan. Jakarta: Sagung Seto.

Deswita. (2006). Psikologi perkembangan.

Bandung: Remaja Rosdakarya.

Djuwita, R. (2006). Kekerasan tersembunyi di sekolah : aspek aspek psikososial dari bullying . Jakarta.

Fajrin, A. N. (2013). Hubungan antara tingkat pengetahuan remaja tentang bullying dengan perilaku bullying pada siswa SMK PGRI Semarang. Semarang: Skripsi. Universitas Muhammadiyah Malang.

Flora, S. R. (2004). The power of reinforcement. New York: State University of New York Press.

Garrison, Karl C. (2003).Psychology Of adolescence.http://getebook.org/ $? p=134515$, diaksestanggal 5 mei 2014.

Ghazi, SafdarRehman. (2010). Parental involvement in children academic motivation. Asian Social Science Vol.6 No.4.University of Science\& Technology.Bannu, Pakistan.

Harnilawati, (2013).Pengantar ilmu keperawatan komunitas. Sulawesi Selatan: Pustaka As Salam
Hastono, S.P. (2007). Analisis data kesehatan. Depok: FKM UI.

Karina. (2013). Perilaku bullying dan karakteri remaja serta kaitannya dengan karakteristik keluarga dan peer group. Jurnal Ilmu Keluarga dan Konsumen Institut Pertanian Bogor, 20-29.

Kazdin, Alan. F. (2008). Parent management training.Yale University School of Medicine. United States.

Komalasari, G. (2011). Teori dan teknik konseling. Jakarta Barat: PT Indeks.

Krahe, B. (2005). Perilaku agresif, buku panduan psikologi sosial. Yogyakarta: Pustaka Pelajar.

L, Sharon. (2009). Behavioral problems in adolescents. Merck Manual Handbook.

Mudjijanti, F. (2011). School bullying dan peran guru dalam mengatasinya. Naskah Krida Rakyat.

Muhith, A. N. (2011). Dasar-dasar keperawatan jiwa. Jakarta: Salemba Medika.

Muir, Katherine A dan Michael A Milan. (2013). Parent reinforcement for child achievement. Journal of applied behavior analysis volume 15 , issue 3 page 455-460. Georgia.

Mulyadi. (2009). Classroom management : mewujudkan suasana kelas yang menyenangkan bagi siswa. Malang: UIN Malang Press. 
Muslikah, R. (2011). Pengaruh implementasi positive reinforcement dalam kelas terhadap tingkah laku siswa kelas xi di man tengaran kabupaten semarang tahun 2011. Salatiga: Skripsi. Sekolah Tinggi Agama Islam Negeri

Notoatmodjo, S. (2003). Pendidikan dan perilaku kesehatan. Jakarta: PT Rineka Cipta.

Notoatmodjo, S. (2010). Metodologi penelitian kesehatan. Jakarta: Rineka Cipta.

Nursalam.(2001). Pendekatan praktis metodologi riset keperawatan. Jakarta: Salemba Medika.

Nursalam. (2008). Pendidikan dalam keperwatan. Jakarta: Salemba Medika.

Papalia, O. F. (2009.) Human development.

Jakarta: Salemba Humanika.

Priyatna, A. (2010). Let's end bullying: memahami, mencegah dan mengatasi bullying. Jakarta: PT Alex Media Komputindo.

Purwanto, E. (2005). Modifikasi perilaku. Jakarta: Departemen Pendidikan Nasional Direktorat Jendral Pendidikan Tinggi Direktorat Pembinaan Pendidikan Tenaga Kependidikan dan Ketenagaan Perguruan Tinggi.

Putra, Sitiatava Rizema. (2012). Panduan riset keperawatan dan penulisan ilmiah. Yogyakarta: D-Medika.

Raharjo, A. S. (2009). Buku kantong sosiologi SMA IPS. Yogyakarta: Penerbit Pustaka Widyatama.

Riauskina, I.I, Djuwita \& Soesetio. (2005). Gencet-gencetan di mata siswa/siswikelas $i$ sma: naskah kognitif tentang arti scenario, dan dampak gencet-gencetan. Jurnal Psikologi Sosial, Vol. 12, No.1.

Robbins, S. P. (2008). Perilaku organisasi. Jakarta: Salemba Empat.

Robiah, Amanatur. (2011).

Pengaruh reinforcement terhadapperilakuanak.Unive rsitasN egeri Jakarta. Jakarta.

Rohman, T. (2007). Sosiologi 1. Jakarta: Yudhistira.

Rudi, T. (2010). Informasi perihal bullying. Indonesian Anti Bullying Edisi Maret, 3.

Saliman. (2011). Kenakalan remaja sebagai perilaku menyimpang. hubungannya dengan keberfungsian sosial

keluarga. Retrieved Agustus 11, 2014, from staff.uny.ac.id: http://staff.uny.ac.id/system/ files/pen gabdian/salimandrs-.

Sanders, C. E. (2004). Bullying implication for the classroom. California: Elsevier Academic Press.

Santrock, J. W. (2003). Adolescence perkembangan remaja. Jakarta: Erlangga. 
Santrock, J. W. (2007). Perkembangan anak.Jakarta: Erlangga.

Sarwono, S. W. (2007). Psikologi remaja. Jakarta: PT Raja Grafindo Persada. Sejiwa. 2008. Bullying. Jakarta: Grasindo.

Setiadi.(2007). Konsep \& penulisan riset keperawatan. Yogyakarta: Graha.

Simamora, Roymond H. (2009). Buku ajar pendidikan dalam keperawatan. Jakarta : EGC

Soeroso, A. (2008). Sosiologi 1. Jakarta: Yudhistira.

Storey, J. (2008). Cultural studies dan kajian budaya pop. Indonesia: Jalasutra.

Sudarwan. (2003). Riset keperawatan sejarah dan metodologi. Jakarta: EGC.

Sunaryo. (2004). Psikologi untuk keperawatan. Jakarta: EGC.

Suprajitno. (2004). Asuhan keperawatan keluarga aplikasi dalam praktik. Jakarta: EGC.

Swarjana, I.K. (2012). Metodologi penelitian kesehatan. Yogyakarta: Andi Offset.

Syaodih, N. (2007). Bimbingan dan konseling dalam praktek. Bandung: Maestro.

Tavris, C. W.( 2009). Psikologi. Jakarta: Erlangga.

Trevi. (2012). Sikap siswa kelas $x$ smk y tangerang terhadap bullying. Jurnal Psikologi Universitas Esa Unggul Vol.1 No.1 Hal.14. Jakarta
Usman, M. U. (2008). Menjadi guru profesional. Bandung: PT Remaja Rosdakarya.

Ventura, Bona danYohannesTobing. (2014). Kekerasan di sekolah kedinasan, belajarlah kepada ki hajar.

http://www.sindoweeklymagz.com/artikel/10/iii/8-14mei-2014/educare/18/kekerasandi- sekolah-kedinasanbelajarlah- kepada-ki-hadjar, diakses tanggal 17 mei 2014.

Wafula, A. L. (2011). Classroom management: the state of positive reinforcement in secondary education in kenya. International Journal of Current Research Vol. 3, Issue, 11, pp.064-067. Kenya.

Wasis. (2008). Pedoman riset praktis untuk profesi perawat. Jakarta:EGC.

Wong, D. L.( 2008). Buku ajar keperawatan pediatrik. Jakarta: EGC 